\title{
Correction to: Percutaneous coronary intervention for chronic total coronary occlusion: Do. Or do not. There is no try
}

\section{P. Knaapen · J. P. Henriques · A. Nap · F. Arslan}

Published online: 18 December 2020

(C) The Author(s) 2020

\section{Correction to:}

Neth Heart J 2020

https://doi.org/10.1007/s12471-020-01531-w

The original version of this article unfortunately contained a mistake. The title was incomplete; the cor-

The online version of the original article can be found under https://doi.org/10.1007/s12471-020-01531-w.

P. Knaapen $(\varangle) \cdot$ J. P. Henriques · A. Nap Department of Cardiology, Heart Center, Amsterdam UMC, University of Amsterdam, Amsterdam Cardiovascular Sciences, Amsterdam, The Netherlands p.knaapen@amsterdamumc.nl

\section{F. Arslan}

Department of Cardiology, Vivantes Klinikum am Urban, Berlin, Germany

rected title is given above. The original article has been corrected.

Open Access This article is licensed under a Creative Commons Attribution 4.0 International License, which permits use, sharing, adaptation, distribution and reproduction in any medium or format, as long as you give appropriate credit to the original author(s) and the source, provide a link to the Creative Commons licence, and indicate if changes were made. The images or other third party material in this article are included in the article's Creative Commons licence, unless indicated otherwise in a credit line to the material. If material is not included in the article's Creative Commons licence and your intended use is not permitted by statutory regulation or exceeds the permitted use, you will need to obtain permission directly from the copyright holder. To view a copy of this licence, visit http://creativecommons.org/licenses/by/4.0/. 